Alves, TRS. (2020). Imagetic Perceptions in Chemistry Textbooks: investigating the subject colligative properties. Research, Society and Development, 9(7), 1-17, e785974443.

\title{
Percepções imagéticas nos livros didáticos de Química: investigando o assunto propriedades coligativas
}

Imagetic perceptions in Chemistry textbooks: investigating the subject colligative properties

\section{Percepciones de imágenes en los libros de texto de Química: investigando el sujeto propiedades coligativas}

Recebido: 12/05/2020 | Revisado: 26/05/2020 | Aceito: 29/05/2020 | Publicado: 14/06/2020

Thiago Rodrigues de Sá Alves

ORCID: https://orcid.org/0000-0003-0412-3078

Instituto Federal do Rio de Janeiro, campus Nilópolis, Brasil

E-mail: thiago.pigead@gmail.com

\section{Resumo}

Sabe-se que os livros didáticos (LD) são repletos de imagens e que elas desempenham um papel relevante na aprendizagem dos estudantes. Diante disso, buscou-se verificar como as imagens estão sendo trabalhadas dentro do conteúdo de Propriedades Coligativas em três livros adotados pelo Programa Nacional do Livro Didático para o Ensino Médio (PNLEM) no ano de 2015. A pesquisa se desenvolveu por meio de uma abordagem qualitativa do tipo documental, além de ter se baseado nos parâmetros de Perales e Jiménez (2002), por meio de instrumentos de análises como funcionalidade, relação com o texto e etiquetas verbais. Os resultados demonstraram que os três livros pesquisados estiveram bem enquadrados nos parâmetros e que suas imagens não ficaram distantes do conteúdo. Com isso, acreditamos que o professor pode optar por utilizar os três livros, tendo, assim, uma aula mais dinâmica e concisa com a utilização de imagens.

Palavras-chave: Ensino e Aprendizagem; Representações Visuais; Sala de Aula.

\begin{abstract}
It is known that textbooks (LD) are full of images and that they play an important role in student learning. Therefore, we sought to verify how the images are being worked within the content of Colligative Properties in three books adopted by the National Textbook Program for High School (PNLEM) in 2015. The research was developed through an approach qualitative
\end{abstract}


documentary type, in addition to having been based on the parameters of Perales and Jiménez (2002), through analysis instruments such as functionality, relationship with the text and verbal labels. The results showed that the three books surveyed were well matched to the parameters and that their images were not far from the content. With this, we believe that the teacher can choose to use the three books, thus having a more dynamic and concise class with the use of images.

Keywords: Teaching and Learning; Visual Representations; Classroom.

\section{Resumo}

Se sabe que los libros de texto (LD) están llenos de imágenes y que juegan un papel importante en el aprendizaje de los estudiantes. Por lo tanto, buscamos verificar cómo se están trabajando las imágenes dentro del contenido de Propiedades Coligativas en tres libros adoptados por el Programa Nacional de Libros de Texto para la Escuela Secundaria (PNLEM) en 2015. La investigación se desarrolló a través de un enfoque tipo documental cualitativo, además de haberse basado en los parámetros de Perales y Jiménez (2002), a través de instrumentos de análisis como funcionalidad, relación con el texto y etiquetas verbales. Los resultados mostraron que los tres libros encuestados coincidían bien con los parámetros y que sus imágenes no estaban lejos del contenido. Con esto, creemos que el maestro puede elegir usar los tres libros, y así tener una clase más dinámica y concisa con el uso de imágenes.

Palabras clave: Enseñando y Aprendiendo; Representaciones Visuales; Aula.

\section{Introdução}

A utilização de imagens está presente na vida do homem desde a pré-história, quando ele as representava por meio da arte rupestre.

Os registros pré-históricos, além de representarem o modo com que esses homens resolviam as adversidades para que a produção artística fosse possível, independentemente de sua finalidade, representam também, através de todos os significados que as gravuras possuem, a cultura imaterial de um povo durante um longo período (Serrano \& Junior, 2020, p. 39).

As imagens, nos dias atuais, estão presentes nos Livros Didáticos (LD) de Química como fotografias, charges, desenhos e são peças fundamentais para uma melhor compreensão dos conceitos que estão sendo discutidos e "possuem um papel mais central na construção e comunicação das ideias científicas do que aqueles tradicionalmente a elas atribuídos, como os 
de meras ilustrações ou de auxiliares na memorização" (Tomio et al., 2013, p. 27). Além disso, seu uso pode vir a ser um recurso didático para o ensino de Química, já que tem a possibilidade de unir teoria e prática quando se quer apresentar os fenômenos químicos. Sebata (2006, p. 42) retrata que "as imagens são representações gráficas de fenômenos, produzidas a partir de observação - com ou sem instrumentos - de fenômenos, sendo essas imagens uma tentativa de representação do real".

O LD é um dos instrumentos mais utilizados nas escolas, e cabe ao professor a tarefa de saber utilizá-lo de forma coerente e eficaz para que o processo de aprendizagem ocorra nos estudantes. Nas palavras de Corazza (2001, p. 66) "o livro didático passa a ser então, um instrumento de ensino e aprendizagem de que cada estudante e educador se servem para experimentar processos de construção de pensamento, de conhecimento".

Na década de 90 foi criado o Programa Nacional de Livro Didático (PNLD), que tem como objetivos a ratificação da qualidade dos LD que estão sendo adotados pelas escolas públicas do país e o comprometimento com a avaliação desses livros antes que possam ser distribuídos para as escolas. Todo esse processo avaliativo é realizado por meio do Guia de Livros Didáticos e, somente após a escolha dos livros, os professores têm acesso e podem optar por trabalhar com os livros em sua escola. Para o ensino médio foi criado, em 2004, o Programa Nacional do Livro Didático para o Ensino Médio (PNLEM) que

prevê a universalização de LD para os alunos do ensino médio público de todo o país. A escolha dos livros é feita por meio do Guia do Livro Didático, com o qual os professores das escolas públicas podem selecionar os livros de sua preferência para serem trabalhados durante um período de três anos. (Maia et al., 2011, p. 115)

Por outro lado, surgem críticas ao mau uso do LD, pois ele pode ser utilizado pelos professores como o único recurso possível "como se fosse um planejamento de curso inteiro que deva ser seguido durante o transcorrer de todo o ano letivo e não como um recurso que deve ser bem empregado em determinado momento" (Isacksson, 2019, p. 200). Acreditamos, assim, que o professor possui total autonomia para aplicar suas metodologias e podem auxiliar na leitura das imagens presentes nos LD

pois a imagem por si só não pode ser considerada uma fonte de aprendizagem. É verdade que toda imagem passa uma mensagem, mas o seu uso na sala de aula, como um suporte à aprendizagem dos conhecimentos científicos e tecnológicos deve ser "orientado", caso contrário a interpretação do fenômeno ou objeto estudado pelos alunos pode ser muito distante do consenso cientifico vigente. (Carneiro et al., 2007, p. 1).

Neste caminho, esta pesquisa buscou verificar como as imagens estão sendo trabalhadas 
no conteúdo de Propriedades Coligativas em três livros adotados pelo PNLEM no ano de 2015.

\section{Metodologia}

O presente trabalho se desenvolveu por meio de uma abordagem qualitativa do tipo documental, já que objetivou realizar a análise de três livros didáticos adotados pelo PNLEM e presentes no Guia do Livro Didático ${ }^{1}$ de 2015 (Tabela 1). Para Gil (2008), a pesquisa documental caracteriza-se pela pesquisa de "materiais que não receberam ainda um tratamento analítico, ou que ainda podem ser reelaborados de acordo com os objetivos da pesquisa" (p. $51)$.

Tabela 1. Informações referentes aos livros didáticos analisados.

\begin{tabular}{|c|c|c|c|c|c|}
\hline Código & Livro & Autores & Editora & Edição & Ano \\
\hline A & $\begin{array}{c}\text { Ser } \\
\text { Protagonista }\end{array}$ & $\begin{array}{c}\text { Obra coletiva. } \\
\text { Editor: Murilo } \\
\text { Tissoni Antunes }\end{array}$ & SM & $2^{\text {a }}$ & 2013 \\
\hline B & Química I & $\begin{array}{c}\text { Martha Reis M. da } \\
\text { Fonseca }\end{array}$ & Ática & $1^{\text {a }}$ & 2013 \\
\hline C & Química I & $\begin{array}{c}\text { Eduardo Fleury } \\
\text { Mortimer e } \\
\text { Andréa Horta } \\
\text { Machado }\end{array}$ & Scipione & $2^{\text {o }}$ & 2013 \\
\hline
\end{tabular}

Fonte: Autoria própria.

Para a pesquisa escolheu-se o assunto Propriedades Coligativas que, nos três livros, está presente no volume 2. A escolha está diretamente ligada à prática docente deste pesquisador ao constatar: dificuldades que seus alunos costumam mostrar durante o entendimento desse assunto, além das dificuldades que possuem ao relacionar esse conteúdo em seu cotidiano. Diante disso, corroboramos com as ideias de Mota (2018) quando afirma que a importância da:

correlação entre conhecimento científico e aspectos do cotidiano, abordados pelo professor, são importantes para compreensão e, consequentemente, facilitam a

\footnotetext{
1 Os livros analisados por esse trabalho estão presentes no Guia do Livro Didático 2015, do site https://www.fnde.gov.br/index.php/programas/programas-do-livro/pnld/guia-do-livro-didatico/item/5940-guiapnld-2015
} 
aprendizagem dos conteúdos escolares, pois despertam o interesse do aluno, incentivando-o quanto a sua participação. (p. 18)

O estudo pautou-se nas ideias de Perales \& Jiménez (2002), que estabeleceram seis instrumentos de análises por meio da categorização de ilustrações, contudo nos concentramos somente em três classificações dessas ilustrações: funcionalidade, relação com o texto principal e etiquetas verbais, ressaltando que cada categoria possui suas subcategorias, que chamaremos aqui de unidades elementares (Tabela 2).

Tabela 2. Categorização das ilustrações e suas unidades elementares.

\begin{tabular}{|c|c|c|}
\hline Categorias & Unidades Elementares & Definição \\
\hline \multirow{3}{*}{ Funcionalidade } & Inoperantes & $\begin{array}{l}\text { A ilustração não apresenta conexão } \\
\text { alguma com o conteúdo, só cabendo, } \\
\text { portanto, observá-la. }\end{array}$ \\
\hline & Operativa elementar & $\begin{array}{l}\text { A ilustração possui elementos comuns } \\
\text { que auxiliam na compreensão, mas que } \\
\text { não sejam especificamente científicos. }\end{array}$ \\
\hline & Sintáticas & $\begin{array}{l}\text { A ilustração possui elementos que } \\
\text { exigem o conhecimento científico mais } \\
\text { específico. }\end{array}$ \\
\hline \multirow{3}{*}{$\begin{array}{l}\text { Relação com o } \\
\text { texto }\end{array}$} & Conotativa & $\begin{array}{l}\text { O texto descreve os conteúdos, sem } \\
\text { mencionar sua correspondência direta } \\
\text { com os elementos contidos na ilustração. } \\
\text { Partimos do princípio que o leitor } \\
\text { consegue fazer a relação/associação do } \\
\text { conteúdo e as ilustrações, sem a } \\
\text { necessidade de mencioná-lo. }\end{array}$ \\
\hline & Denotativa & $\begin{array}{c}\text { Existe a correspondência entre os } \\
\text { elementos da ilustração com os } \\
\text { conteúdos que estão sendo representados } \\
\text { no texto. }\end{array}$ \\
\hline & Sinóptica & $\begin{array}{l}\text { A imagem precisa vir acompanhada de } \\
\text { um texto, formando uma unidade } \\
\text { indivisível. }\end{array}$ \\
\hline \multirow{3}{*}{ Etiquetas verbais } & Sem etiqueta & Ilustrações sem legenda. \\
\hline & Nominativa & $\begin{array}{l}\text { Somente possuem letras ou palavras que } \\
\text { identificam alguns elementos da } \\
\text { ilustração. }\end{array}$ \\
\hline & Relacionável & $\begin{array}{c}\text { Textos que descrevem as relações entre } \\
\text { os elementos da ilustração (as ilustrações } \\
\text { possuem identificação) }\end{array}$ \\
\hline
\end{tabular}

Fonte. Adaptado de: Perales \& Jiménez (2002). 
A categoria funcionalidade das ilustrações, primeira desse estudo, retrata como as ferramentas gráficas podem ser utilizadas com a função de exprimir ideias e, nas palavras dos autores, essa utilização "costuma ser algo habitual, tanto nas atividades de ensino aprendizagem das ciências como nos textos representativos do conteúdo científico" (Perales \& Jiménez, 2002, p. 377, tradução nossa). As unidades elementares da funcionalidade das ilustrações podem ser: inoperantes, operativas elementares ou sintáticas.

Na segunda categoria, relação com o texto, pode-se identificar uma relação estabelecida entre o texto e as imagens, sendo que as informações que encontramos em imagens, acabam, na maioria das vezes, se tornando descontínuas. As unidades elementares dessa categoria são: conotativa, denotativa ou sinóptica, cujas descrições estão na Tabela 2.

Enquanto o texto sustenta o conjunto do discurso narrativo ou argumentativo, as ilustrações mostram aspectos parciais; em outras palavras, a informação incluída nas imagens é descontínua e só sua inclusão no conjunto lhe dá significado (Perales \& Jiménez, 2002, p. 377, tradução nossa).

A terceira e última categoria são as etiquetas verbais, textos que aparecem nas ilustrações e contribuem para a sua interpretação. São divididas em normativas, relacionáveis ou sem etiqueta.

Diante disso, partiu-se para a análise dos livros de acordo com as categorias estabelecidas a priori.

\section{Resultados e Discussão}

Analisou-se um total de 63 representações visuais do conteúdo programático de Propriedades Coligativas, presentes no volume 2 de três livros do Guia do Livro Didático de 2015. Desse quantitativo, 26 imagens são referentes ao Livro A, 19 ao Livro B e 18 ao Livro C. Inicialmente constatou-se que as três obras possuem diferenças, que serão apresentadas e discutidas na Tabela 3 mostrando as categorias e as unidades elementares nas quais as imagens dos livros se enquadraram durante a análise. 
(CC BY 4.0) | ISSN 2525-3409 | DOI: http://dx.doi.org/10.33448/rsd-v9i7.4443

Tabela 3. Resultado da análise dos três livros do PNLEM.

\begin{tabular}{|c|c|c|c|c|}
\hline Categorias & Unidades Elementares & Livro A & Livro B & Livro C \\
\hline \multirow{3}{*}{ Funcionalidade } & Inoperantes & 0 & 0 & 0 \\
\cline { 2 - 5 } & Operativas elementares & 13 & 15 & 9 \\
\cline { 2 - 5 } & Sintáticas & 13 & 4 & 9 \\
\hline \multirow{3}{*}{ Relação com o texto } & & & & 2 \\
\cline { 2 - 5 } & Conotativa & 1 & 7 & 16 \\
\cline { 2 - 5 } & Denotativa & 6 & 5 & 0 \\
\hline \multirow{3}{*}{ Etiquetas verbais } & Sinóptica & 2 & 0 & 1 \\
\cline { 2 - 5 } & & 0 & 4 & 3 \\
\cline { 2 - 5 } & Sem etiqueta & 24 & 15 & 14 \\
\hline
\end{tabular}

Fonte: Autoria própria

\subsection{Quanto à funcionalidade}

Durante a análise do Livro A, as unidades elementares operativa elementar e sintática, que se encontram na categoria funcionalidade, foram identificadas com o mesmo quantitativo (13). É importante ressaltar que tratamos a primeira como imagens que ajudam na compreensão por meio de elementos comuns e que não precisam ser especificamente científicos. A Figura 1 retrata essa compreensão ao mostrar que a secagem de roupas no varal trata-se de um processo de evaporação e não é necessário, portanto, que o leitor tenha um conhecimento científico para compreender a ideia de que a imagem está passando.

Figura 1. Exemplo de uma imagem do tipo operativa elementar.

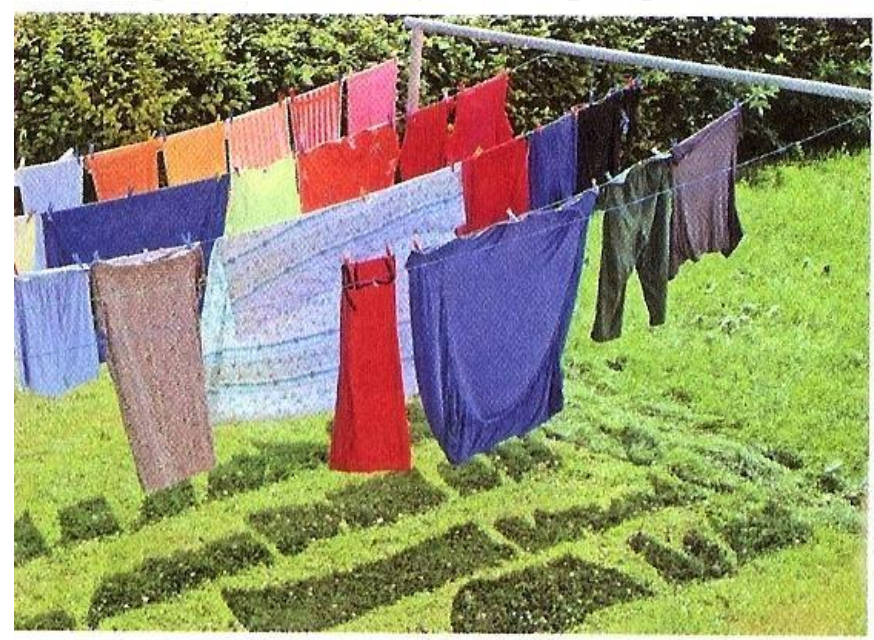

Fonte: Antunes, MT. (2013). Ser protagonista: química

As imagens da unidade sintática tratam de um conhecimento de cunho científico e que somente por meio delas o leitor com pouco domínio do tema abordado teria dificuldades para 
identificar com clareza o que o conteúdo se propõe a discutir (Figura 2)

Figura 2. Exemplo de uma imagem do tipo sintática.

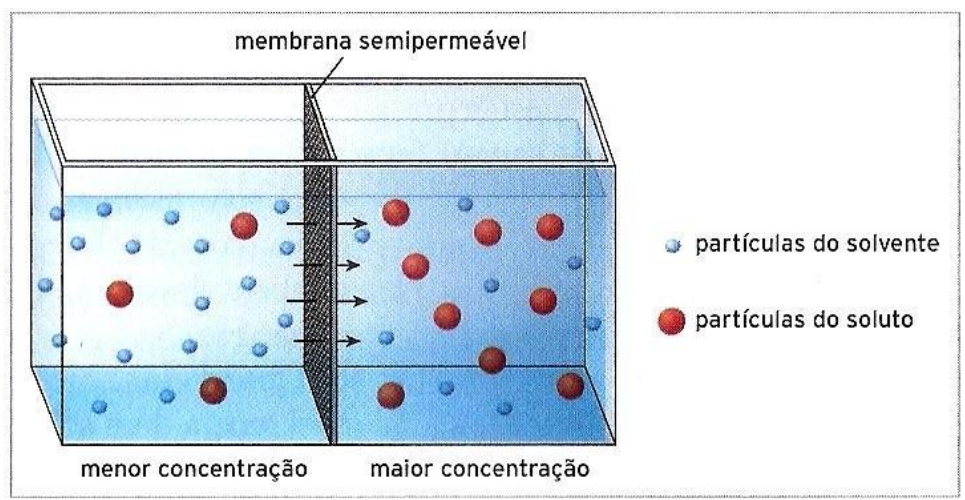

Fonte: Antunes, MT. (2013). Ser protagonista: química

Nessa figura pode-se verificar a passagem de um solvente por meio de duas soluções que possuem concentrações diferentes e que acabam entrando em contanto através de uma membrana semipermeável, onde o solvente vai do menos concentrado para o mais concentrado. Esse processo é conhecido como osmose.

Se tal membrana é colocada entre duas soluções de diferentes concentrações, as moléculas do solvente movimentam-se em ambos os sentidos pela membrana. Entretanto, a concentração do solvente é mais alta na solução contendo menos soluto, logo a taxa na qual o solvente passa da solução menos concentrada para a mais concentrada é maior que a taxa no sentido oposto. Portanto, existe um movimento resultante de moléculas do solvente da solução menos concentrada para a solução mais concentrada. Nesse processo, chamado osmose, o movimento resultante do solvente é sempre no sentido da solução com a maior concentração de soluto (Brown, Lemay \& Burste, 2005, p. 466)

No Livro B, por outro lado, foram identificadas 15 unidades elementares do tipo operativas elementares e somente 4 sintáticas. Isso demonstra que, para discutir os assuntos referentes ao conteúdo de Propriedades Coligativas, o leitor consegue, por meio das imagens operativas elementares, associá-las ao seu cotidiano sem a necessidade de um conhecimento científico.

As imagens presentes no Livro C, quanto à categoria funcionalidade, tiveram o mesmo quantitativo nas operativas elementares e sintáticas. Dos três livros analisados, somente o livro B apresentou um quantitativo superior aos demais (15), dentro da unidade operativa elementar.

As imagens de todos os livros foram coerentes ao que estivemos pesquisando, e concordamos com Dib et al. (2003, p. 3) quando as autoras falam que o nosso alunado "deve 
saber ler e interpretar as imagens, pois o domínio desses processos tem relação direta com a aprendizagem de conhecimentos científicos". Também foi constatado que em nenhum dos três livros pesquisados encontramos, dentro da categoria funcionalidade, a unidade elementar do tipo inoperante que é justamente quando as ilustrações estão totalmente desconectadas do conteúdo.

\subsection{Quanto à relação com o texto}

Dentro da segunda categoria, relação com o texto, identificou-se que o Livro A possui apenas 1 imagem com a função conotativa (Figura 3), onde parte do princípio de que o leitor consegue associar o conteúdo com a imagem, sem a necessidade desse conteúdo ser mencionado.

Figura 3. Exemplo de uma imagem do tipo conotativa.

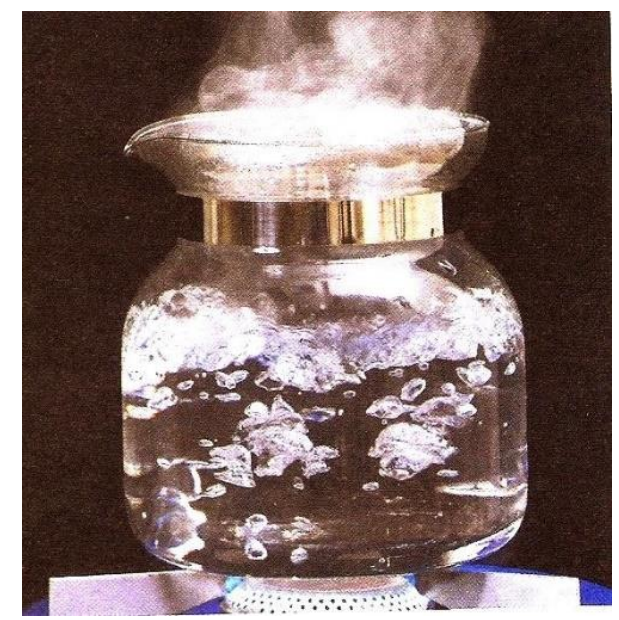

Fonte: Antunes, MT. (2013). Ser protagonista: química

Nesse livro identificou-se que a função denotativa foi a mais presente, com 19 imagens (Figura 4), seguida da função sinóptica, com 6 imagens. 
Figura 4. Exemplo de uma imagem do tipo denotativa.

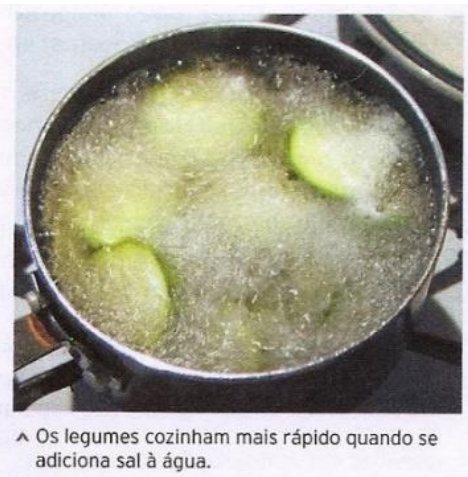

Por que os alimentos cozinham mais rápido quando se adiciona sal à água? O tempo de cozimento de um alimento depende da temperatura em que ele é preparado. Assim, ao nível do mar a temperatura de ebulição da água é $100^{\circ} \mathrm{C}$. Se você adicionar sal à água, ela entrará em ebulição a uma temperatura acima de $100^{\circ} \mathrm{C}$, diminuindo o tempo de cozimento do alimento. Quanto mais concentrada for a soluçāo, maior será o efeito ebulioscópico, isto é, maior será o aumento da temperatura de ebulição da água.

Fonte: Antunes, MT. (2013). Ser protagonista: química

Esses resultados nos fazem refletir que esse livro preconizou imagens que estão diretamente ligadas com o texto principal dando, assim, facilidade para o entendimento do conteúdo. Perales (2006) ressalta que

as imagens ajudam mais em textos complexos do que em textos simples. Neste último caso, quando são altamente concretos e atraentes, favorecem facilmente as imagens visuais e, portanto, é improvável que a inclusão de imagens produza benefícios cognitivos adicionais (p. 20).

O Livro B mostrou 5 imagens do tipo sinóptica (Figura 5) e um mesmo quantitativo para imagens conotativas e denotativas (7). 
Figura 5. Exemplo de uma imagem do tipo sinóptica.

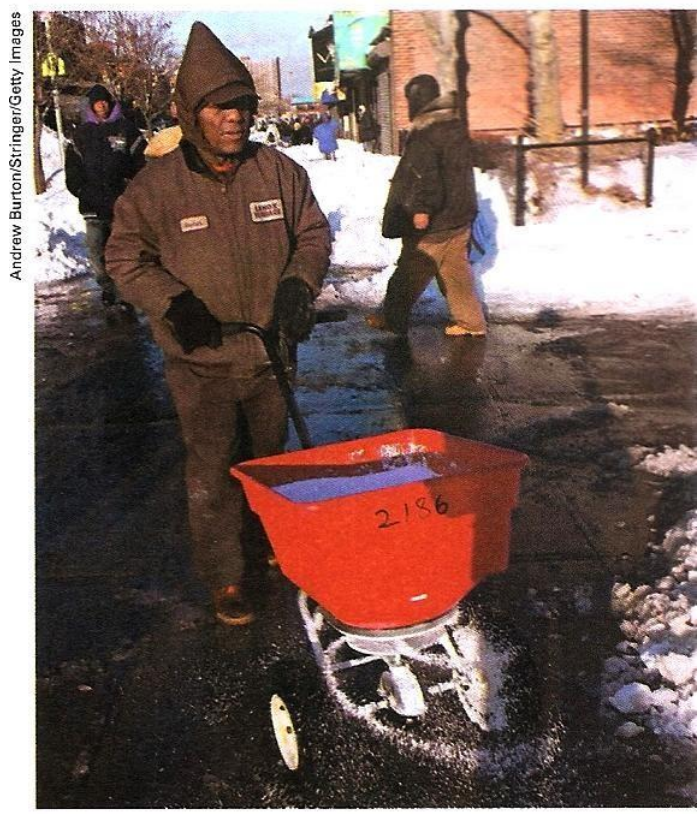

É costume, no inverno em países frios, jogar sais, como cloreto de sódio, $\mathrm{NaCl}(\mathrm{s})$, ou cloreto de cálcio, $\mathrm{CaCl}_{2}(\mathrm{~s})$, nas ruas e autoestradas para dificultar a formação de uma camada de gelo, o que causaria a diminuição do coeficiente de atrito e consequentemente um aumento no risco de acidentes.

Fonte: Reis, M. (2013). Química

Muitas imagens desse livro foram enquadradas na unidade elementar conotativa por aparecerem antes do texto de estudo, e por não terem sido nele mencionadas. A leitura do texto principal sem o acompanhamento de uma imagem pode tornar a compreensão do conteúdo difícil para o leitor.

A imagem tem a importância de ajudar na visualização agradável da página. Se há textos muito longos, ela serve para quebrar o ritmo cansativo da leitura. Além disso, ela pode sugerir leituras, apoiá-las do ponto de vista do enredo, construir formas, personagens, cenários, enfim, compor, junto com o texto verbal, um horizonte de leitura (Belmiro, 2000, p. 23)

No Livro C, identificou-se 2 imagens conotativas, 16 denotativas e nenhuma imagem do tipo sinóptica. Os Livros A e C se mostraram fiéis aos parâmetros de Perales \& Jiménez (2002), com maior quantidade para a unidade elementar denotativa. Isso é importante porque o leitor consegue ter um melhor entendimento dos conceitos que estão sendo apresentados justamente por essa união entre as imagens e o texto principal. Por outro lado, houve falta de 
(CC BY 4.0) | ISSN 2525-3409 | DOI: http://dx.doi.org/10.33448/rsd-v9i7.4443

imagens do tipo sinóptica no Livro $\mathrm{C}$ e com isso salientamos sobre a importância de tanto o texto, quanto a imagem, estarem integrados com o objetivo de facilitar a compreensão dos conceitos pelo leitor. Ainda dentro da unidade elementar sinóptica é importante sinalizar que

O texto descreve a correspondência entre os elementos da ilustração e o conteúdo representado e estabelece as condições nas relações entre os elementos incluídos na ilustração que representam as relações entre o conteúdo, de modo que a imagem e o texto formam uma unidade indivisível. (Perales \& Jiménez, 2002, p. 377, tradução nossa)

\subsection{Quanto à etiqueta verbal}

A última unidade elementar de nossa análise, etiquetas verbais, também se mostrou fiel aos parâmetros de estudo. No Livro A, que teve 26 imagens pesquisadas, identificamos um total de 24 imagens com etiqueta verbal do tipo relacionável (Figura 6) e somente 2 imagens sem etiqueta, ou seja, a imagem estava presente no livro didático, mas sem uma referência, o que acaba descaracterizando a mesma. Nesse livro não foi encontrada imagem do tipo nominativa, que é quando existem "letras ou palavras que identificam alguns elementos da ilustração" (Perales \& Jiménez, 2002, p. 378, tradução nossa).

Figura 6. Exemplo de uma imagem do tipo relacionável.

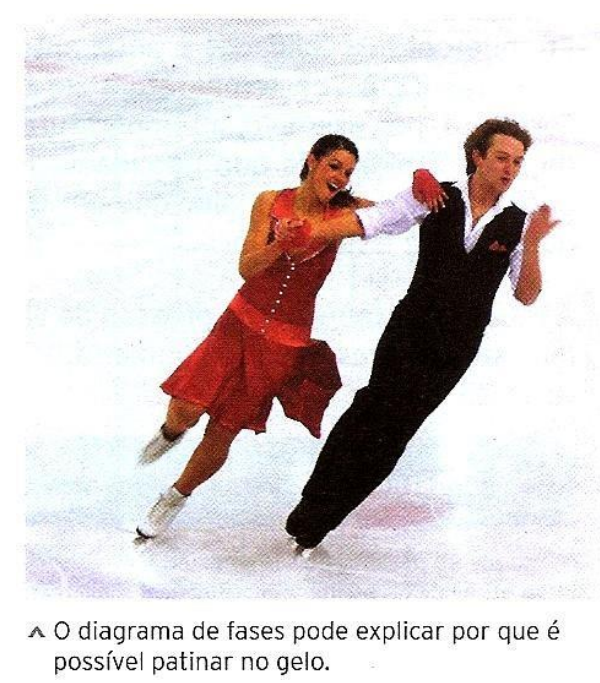

Fonte: Antunes, MT. (2013). Ser protagonista: química

O Livro B teve 15 imagens do tipo relacionável e 4 do tipo nominativa (Figura 7) o que mostra que as etiquetas relacionáveis podem contribuir para a união entre o texto e a imagem.

É essencial direcionar o processo de exploração das ilustrações através de etiquetas 
Research, Society and Development, v. 9, n. 7, e785974443, 2020

(CC BY 4.0) | ISSN 2525-3409 | DOI: http://dx.doi.org/10.33448/rsd-v9i7.4443

verbais ou tarefas que obrigam os leitores a extrair informações deles. A concordância apropriada das imagens e as palavras que as acompanham é um fator determinante para tirar proveito do potencial didático de uma ilustração (Perales, 2006, p. 25)

Figura 7. Exemplo de uma imagem do tipo nominativa.
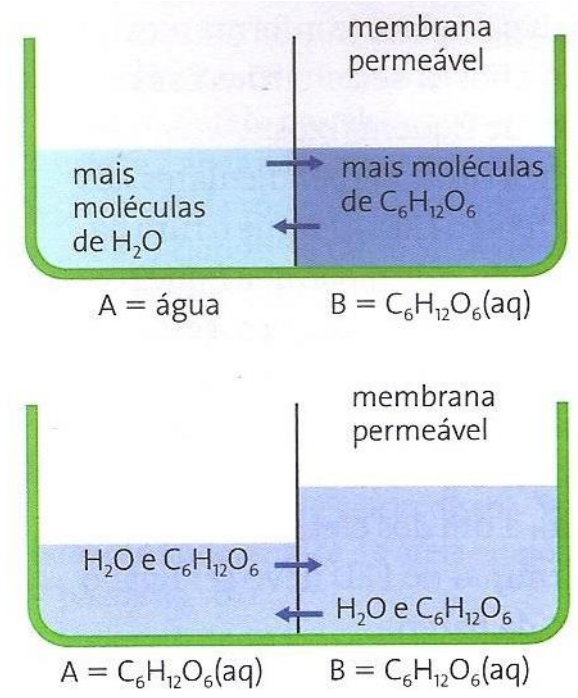

Fonte: Reis, M. (2013). Química

No Livro $\mathrm{C}$, identificou-se 14 imagens do tipo relacionável, 3 do tipo nominativa e somente 1 sem etiqueta (Figura 8). Quanto à essa última é interessante mencionar que quando as figuras não possuem etiqueta verbal são vistas como independentes, pois não há necessidade de palavras com o intuito de trazer sentido para as figuras. Ainda dentro dessa categorização, o Livro A se sobressaiu aos demais livros analisados, porém ressaltando que os outros dois estiveram coerentes à pesquisa.

Figura 8. Exemplo de uma imagem do tipo sem etiqueta.

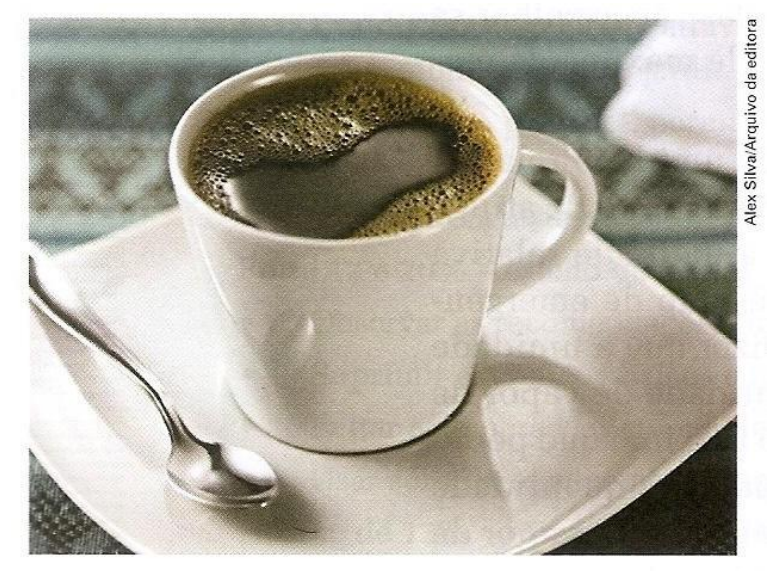

Fonte: Mortimer, EF \& Machado, AH. (2013) Química. 
As imagens dos livros analisados, por meio dos parâmetros já citados, mostram que elas não estão desconectadas com o texto principal, o que torna o entendimento do conteúdo abordado mais fácil ao leitor. Acreditamos nas palavras de Sousa \& Barrio (2017) quando salientam que

As representações visuais têm sido cada vez mais utilizadas nos livros didáticos, como uma tentativa de estimular o interesse dos estudantes e promover melhorias na qualidade do processo de ensino e aprendizagem, seja através de ilustrações, intercalando ao texto verbal, seja como forma de explicação complementando o texto. (p. 2)

É importante ressaltar que há diversas maneiras quanto ao processo de ensino e aprendizagem e que o uso de imagens presentes nos LD não objetiva somente ilustrar os fatos e sim trazer uma reflexão ao leitor sobre os assuntos apresentados de forma a relacionar-se com situações que envolvam seu cotidiano.

O processo de ensinar e aprender exige um pensamento crítico, por parte do professor e do aluno, visto que os conteúdos são repletos de conceitos, muitos dos quais são abstratos e geralmente de difícil compreensão, especialmente quando os alunos são colocados em uma posição de acreditar em algo tão microscópico e invisível a olho nu. (Silva, 2020, p. 34)

\section{Considerações Finais}

O trabalho buscou verificar como as imagens, dentro do conteúdo de Propriedades Coligativas, foram trabalhadas em três livros adotados pelo PNLEM no ano de 2015. Para isso foram utilizadas as classificações provenientes dos estudos de Perales e Jiménez (2002), por meio de três instrumentos de analise: funcionalidade, relação com o texto principal e etiquetas verbais. Dentro do primeiro instrumento identificou-se que o Livro B apresentou 19 representações visuais, sendo $79 \%$ de imagens do tipo operativa elementar e somente com $21 \%$ de imagens do tipo sintática, essa última exigindo que o leitor tenha um conhecimento científico mais específico para compreender o tipo de figura vista por ele. Os demais livros, A e C, estiveram com 50\% das imagens em cada unidade elementar. No segundo instrumento de estudo, relação com o texto, o Livro C ficou à frente de todos com 88,9\% de imagens do tipo denotativa e $11,1 \%$ do tipo sinóptica. O livro A veio em seguida com $73,1 \%$ de imagens denotativas, $23,1 \%$ de imagens sinópticas e 3,9\% de imagens conotativas. Na última categoria, etiquetas verbais, o Livro A esteve com 92,3\% de imagens do tipo relacionável, ou seja, os textos estavam corretamente relacionados com as ilustrações, e somente com 7,7\% de imagens 
do tipo sem etiqueta. Os Livros B e C, com relação a imagens do tipo relacionável, estiveram com $79 \%$ e $77,8 \%$, respectivamente.

Por outro lado ressaltamos que o professor, ao lecionar um assunto em sala de aula, deve estar atento em como trabalhar as imagens dentro dos conteúdos de química presentes no LD, além de saber que o livro é "uma importante ferramenta na construção do conhecimento científico, da visão crítica em relação ao meio no qual os alunos se inserem e da cidadania"(Silva \& Prazeres, 2020, p. 164).

As imagens presentes nos LD precisam estar além do aspecto ilustrativo, quando temos uma leitura agradável, e devem estar diretamente conectadas com o texto, pois só assim teremos uma complementação e, principalmente, um momento de reflexão para o leitor. Portanto, "as ilustrações facilitam a compreensão dos textos ajudando a produzir um modelo mental da informação contida neles somente se existe uma correta interpretação das imagens" (Perales \& Jiménez, 2002, p. 383, tradução nossa).

\section{Referências}

Antunes, M. T. (2013). Ser protagonista: química. São Paulo: Edições SM.

Batista, A. P. (2011). Uma Análise da relação professor e o livro didático. Monografia, Universidade do Estado da Bahia - UNEB: Salvador.

Belmiro, C. A. (2000). A imagem e suas formas de visualidade nos livros didáticos de Português. Educação \& Sociedade, 21(72), 11-31. https://doi.org/10.1590/S010173302000000300002

Brown, T. L, Lemay, H. E \& Bursten, B. E. (2005) Química: a ciência central. Trad. RM Matos. 9 ed. São Paulo: Pearson Prentice Hall

Corazza, S. M (2011). Construtivismo pedagógico como significado transcendental do currículo. Coleção Educação. São Paulo.

Dib, S. M. F, Mendes, J. R. S \& Carneiro, M. H. S. (2003). Texto e Imagens no Ensino de Ciências. In: IV Encontro Nacional de Pesquisa em Educação em Ciências. 1-8. 
Recuperado de http://fep.if.usp.br/ profis/arquivos/ivenpec/Arquivos/Orais/ORAL166.pdf

Isacksson, I. (2019). A importância do livro didático no ensino de línguas. Psicologia \& Saberes, 8(12), 191-203. Recuperado de https://revistas.cesmac.edu.br/index.php/ psicologia/article/view/1086/833

Jiménez, J. D, Perales, F. J. (2002). Las ilustraciones em la enseñanza-aprendizaje de las ciencias: análisis de libros de texto. Enseñanza de las Ciencias, 20(3), 369-386. Recuperado de https://ddd.uab.cat/pub/edlc/02124521v20n3/02124521v20n3p369.pdf

Maia, J. O, Sá, L. P, Massena, E. P. \& Wartha, E. J. (2011). O Livro Didático de Química nas Concepções de Professores do Ensino Médio da Região Sul da Bahia. Química Nova na Escola. 33(2) Recuperado de http://qnesc.sbq.org.br/online/qnesc33_2/07-PE7110.pdf

Mortimer, E. F \& Machado, A. H. (2013) Química. 2. ed. São Paulo: Scipione.

Mota, M. R. S. (2018). O ensino de ciências nos anos iniciais: concepções docentes acerca da contextualização e de sua prática (Dissertação de mestrado). Universidade Federal de Sergipe, SE, Brasil. Recuperado de https://ri.ufs.br/bitstream/riufs/8304/2/maria_ rivanusia_santana_mota.pdf

Perales, F. J. (2006). Uso (y abuso) de la imagen en la enseñanza de las ciencias. Enseñanza de las Ciencias, 24(1). 3-30. Recuperado de https://core.ac.uk/download/pdf/38989884.pdf

Reis, M. (2013). Química. 1. ed. São Paulo: Ática.

Sebata, C. E. (2006). Aprendendo a imaginar moléculas: uma proposta de ensino de geometria molecular (Dissertação de mestrado). Universidade de Brasília, Brasília, Brasil. Recuperado de http://ppgec.unb.br/wp-content/uploads/dissertacoes/2006/2006_ClaudioSebata.pdf

Serrano, S. F \& Junior, D. R. (2020). A arte rupestre do sítio arqueológico pedra escrita e sua relação com a paisagem. In: Vasconcelos, AWS. (Org.). Discussões Interdisciplinares no Campo das Ciências Humanas (1a ed., 37-56) Ponta Grossa PR: Atena 
Silva, R. A. M. (2020). Construção e emprego de um protótipo funcional para ensino e aprendizagem em química: a importância das concepções prévias dos estudantes.

(Dissertação de mestrado). Universidade Estadual Paulista, São Paulo, Brasil. Recuperado de https://repositorio.unesp.br/bitstream/handle/11449/192391/silva_ram_me_bauru.pdf?sequenc $\mathrm{e}=3$ \&isAllowed $=y$

Sousa, R. M \& Barrio, J. B. M. (2017). A célula em imagens: uma análise dos livros didáticos de Biologia aprovados no PNLD 2015. In: XI Encontro Nacional de Pesquisa em Educação em Ciências ? XI ENPEC. 1-10. Recuperado de http://www.abrapecnet.org.br/enpec/xienpec/anais/resumos/R0502-1.pdf

Silva, M, V, \& Prazeres, J. A. (2020). A temática "algas” em livros didáticos do ensino fundamental: uma análise teórica e imagética segundo o modelo da carga cognitiva e da teoria da memória operacional. Biodiversidade, 19(1), 162-173. Recuperado de http://www.periodicoscientificos.ufmt.br/ojs/index.php/biodiversidade/article/download/10 $002 / 6795$

Tomio, D., Grimes, C, Ronchi, D. L, Piazza, F., Reinicke, K., \& Pecini, V. (2013) . As imagens no ensino de ciências: o que dizem os estudantes sobre elas?. Caderno Pedagógico (Lajeado Online), 10(1), 25-40. Recuperado de http://www.univates.br/revistas/index.php/cadped/ article/download/869/858

\section{Porcentagem de contribuição de cada autor no manuscrito}

Thiago Rodrigues de Sá Alves - 100\% 